\title{
FENOMENOLOGI PELAKU USAHA SARI BUMI SEBAGAI ENTREPRENEUR MUSLIM DALAM MEMBANGUN KONEKSI DAN KOMUNITAS BISNIS
}

\author{
Ana Aziza \\ Sidoarjo \\ aidilaeputra@gmail.com
}

\begin{abstract}
In Indonesia, the entrepreneurial culture is quite low. This can be seen from the very high interest of job seekers, high rates of poverty and unemployment. From the above phenomenon, the role of Muslims as the majority is needed to encourage the growth of the entrepreneurial spirit. This study seeks to portray the role of Sari Bumi entrepreneurs in building connections and business communities, using a phenomenological approach, researchers seek to explore what roles Sari Bumi entrepreneurs have played in building connections and business communities. Based on the results of the study, there have been 158 building material shops in Sidoarjo Regency which have been owned by 80 families. Based on data analysis in qualitative research, it was found 9 (nine) roles of Sari Bumi entrepreneurs in building a business community which include, opening up employment opportunities, building independence, encouraging the emergence of an entrepreneurial spirit, providing capital assistance, being an example in discipline, commitment to maintaining Islamic values, forming a forum for friendship, forming a foundation that is active in the social, educational and religious fields and establishing a distributor company.
\end{abstract}

Keywords: Muslim entrepreneurs, connections and the business community.

Abstrak: Di Indonesia budaya entrepreneur masih sangat rendah, hal ini dapat dilihat dari minat para pencari kerja yang sangat tinggi, tingginya angka kemiskinan dan penggangguran. Dari fenomena diatas dibutuhkan peran umat Islam sebagai umat mayoritas untuk mendorong tumbuhnya jiwa entrepreneur. Penelitian ini berupaya untuk memotret peran entrepreneur Sari Bumi dalam membangun koneksi dan komunitas bisnis, dengan menggunakan pendekatan fenomenologi, peneliti berupaya untuk menggali peran apa saja yang telah dilakukan para entrepreneur Sari Bumi dalam membangun koneksi dan komunitas bisnis. Berdasarkan hasil penelitian terdapat 158 toko bahan bangunan di Kabupaten Sidoarjo yang dimiliki oleh 80 kepala keluarga. Berdasarkan analisa data dalam penelitian kualitatif ditemukan 9 (Sembilan) peran entrepreneur Sari Bumi dalam membangun komunitas bisnis yang meliputi, membuka lapangan pekerjaan, membangun kemandirian, mendorong timbulnya jiwa entrepreneur, memberi bantuan modal, menjadi teladan dalam kedisiplinan, komitmen dalam menjaga nilai keislaman, membentuk wadah silaturahmi, membentuk yayasan yang berkiprah pada bidang sosial, pendidikan dan keagamaan dan mendirikan perusahaan distributor.

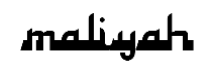

Jurnal Hukum Bisnis Islam

Volume 9 Nomor 2, Desember 2019

p-ISSN: 2088-4869/ e-ISSN: 2597-4351 
Fenomenologi Pelaku Usaha Sari Bumi Sebagai Entrepreneur Muslim Dalam ...

Kata Kunci: Entrepreneur muslim, koneksi dan komunitas bisnis.

\section{Pendahuluan}

Perkembangan kewirausahaan beberapa tahun terakhir telah menjadi isu penting pada lembaga perekonomian, mulai dari tingkat daerah, nasional bahkan internasional. Kecenderungan ini karena kewirausahaan telah menjadi kunci untuk sejumlah hasil-hasil sosial yang diinginkan termasuk pertumbuhan ekonomi dan penurunan angka pengangguran. Kewirausahaan memegang peranan penting bagi kemakmuran suatu negara. Bagi pemerintah, kewirausahaan sangat penting untuk tujuan ekonomis maupun politik. Secara ekonomis, kewirausahaan akan membantu meningkatkan pendapatan masyarakat, juga meningkatkan kesejahteraan masyarakat melalui penciptaan produk baru dengan kwalitas yang lebih baik dan harga yang lebih murah, serta mengurangi tingkat pengangguran dan kemiskinan. Dari segi politik, suatu pemerintahan yang tidak berhasil meningkatkan pendapatan masyarakat dan mengurangi jumlah pengangguran dan kemiskinan akan menjadi tidak popular, sehingga dalam pemilu berikutnya peluang untuk terpilih kembali akan lebih kecil.

Schumpeter dalam Darwanto menyatakan entrepreneur mempunyai andil besar dalam pertumbuhan ekonomi, yaitu melalui penciptaan inovasi, lapangan kerja dan kesejahteraan. Dunia usaha yang dibangun oleh entrepreneur akan mendorong perkembangan sektor- sektor produktif. Semakin banyak suatu negara memiliki entrepreneur, maka pertumbuhan ekonomi negara tersebut akan semakin tinggi. Ada lima kombinasi yang dibentuk oleh entrepreneur, antara lain: memperkenalkan produk baru dengan kwalitas baru; memperkenalkan metode produksi baru; membuka pasar baru; memperoleh sumber 
pasokan baru dari bahan baku baru dan komponen baru serta menjalankan organisasi dalam industri baru. ${ }^{1}$

Ajaran Islam sangat menganjurkan umatnya untuk berwirausaha. Bahkan seorang utusan yang bertugas menyampaikan risalah Islam kepada seluruh umatnya yaitu, nabi Muhammad SAW adalah seorang yang dilahirkan dari keluarga entrepreneur. Kakek besar beliau, Hasyim bin Abdul Manaf adalah seorang saudagar besar penentu jalur perdagangan Syria-Makkah-Yaman pemangku kebijakan perdagangan suku Quraisy. Kakek beliau yang mengasuh nabi Muhammad sejak kecil yaitu Abdul Muthalib adalah seorang pedagang besar di Makkah. Nabi Muhammad sejak berusia 12 tahun sudah memiliki spirit entrepreneurship. Beliau merintis karier dagangnya sejak berusia 12 tahun sampai berusia 37 tahun. Bahkan, karier beliau sebagai entrepreneur lebih lama dibanding tugas mengemban wahyu. ${ }^{2}$

Membangun dunia usaha bukanlah suatu perkara yang sederhana. Dibutuhkan mental yang kuat agar senantiasa dapat bertahan di tengah pesatnya persaingan bisnis dalam kondisi ekonomi makro yang senantiasa berubah. Demikian halnya dengan usaha yang dilakukan oleh keluarga besar Sari Bumi. bermula dari hijrahnya Haji Muntaham dari desa Brangsih, Lamongan menuju kota Surabaya pada tahun 1982. Beliau memulai usahanya dengan mengontrak rumah di daerah rungkut industri, kemudian untuk menjalankan usahanya melibatkan para keponakannya. Ada juga di antaranya yang masih kuliah dengan bekerja paruh waktu. Setelah lulus kuliah dan menikah mereka diberi kepercayaan untuk mengelola toko milik Haji Muntaham. Kemudian setelah ponakkannya tersebut

\footnotetext{
${ }^{1}$ Darwanto, Peran Entrepreneurship Dalam Mendorong Pertumbuhan Ekonomi Dan Meningkatkan Kesejahteraan Masyarakat (Semarang: Diseminasi Riset Terapan Bidang Manajemen dan bisnis Tingkat Nasional Jurusan Politehnik Negeri Semarang, 2012).12

2 Muhamad Syafii Antonio, Ensiklopedi Leadership \& Manajemen The Super Leader Super Manager, Seri Business \& Entrepreneurship (Jakarta: Tazkia Publising, 2010).12
} 
memiliki modal sendiri, mereka membuka toko sendiri, begitu seterusnya sehingga banyak sekali toko Sari Bumi yang ada di kabupaten Sidoarjo. Dari data penelitian awal terdapat 80 orang pemilik toko bahan bangunan yang tergabung dalam keluarga besar Sari Bumi, masing masing dari mereka ada yang hanya memiliki satu toko, dua toko, tiga toko bahkan ada yang memiliki 13 toko, sehingga saat ini ada 158 (seratus lima puluh delapan) toko bahan bangunan di Sidoarjo yang tergabung dalam keluarga besar Sari Bumi. ${ }^{3}$

Komunitas entrepreneur Sari Bumi ini memiliki wadah sebagai pertemuan rutin mereka, yaitu forum arisan keluarga yang mereka kemas dengan taklim agama, acara ini biasa mereka lakukan pada hari jumat minggu pertama dan ketiga setiap bulannya. Selain sebagai komunitas entrepreneur, Sari Bumi juga memiliki lembaga pendidikan formal yaitu lembaga pendidikan Sari Bumi yang berdiri pada tahun 2009. Lembaga ini terdiri dari Taman Pendidikan al-Qur'an (TPQ), Pendidikan Anak Usia Dini (PAUD) dan Sekolah Dasar (SD Sari Bumi).

Fenomena tersebut menarik untuk diteliti, bagaimana peran entrepreneur muslim Sari Bumi dalam membangun komunitas, koneksi dan menjaga keberlangsungan usahanya, sehingga saling menguatkan, saling menopang untuk mencapai kesuksesan dan kesejahteraan bersama, bahkan dapat berkembang dari generasi ke generasi berikutnya.

\section{Entrepreneurship dan Entrepreneur Muslim}

Entrepreneur atau (wirausaha), berasal dari kata bahasa Perancis entreprendre yang berarti "melakukan" (to undertake) atau mencoba (trying). Dalam kamus bahasa Indonesia "wirausaha", identic dengan wiraswasta yang artinya orang yang pandai atau berbakat mengenali produk, menentukan cara pruduksi baru, menyusun operasi untuk pengadaan

\footnotetext{
3 Amsikul Ma'arif, “wawancara”, Toko Sari Bumi Bangunan Urang Agung, 04 Februari 2018.
} 
produk baru, memasarkannya, serta mengatur permodalan operasinya. ${ }^{4}$

Dalam bahasa Indonesia yang sederhana wirausaha dapat dimaknai sebagai sebuah kemampuan (an ability) yang didalamnya termasuk dalam usaha (effort), aktifitas, aksi, tindakan dan lain sebagainya untuk menghasilkan suatu tugas (task). Arti atau makna wirausaha yang kita ketahui saat ini diawali oleh pemikiran dari studi yang dilakukan oleh para ekonom terkemukan pada abad 18 dan 19. Para ekonom seperti Richard Cantilon (1725), J.B. Say (1805) dan Joseph Scumpeter (1934), mereka telah memberikan definisi tentang wirausaha. Richard Cantilon memberikan definisi tentang wirausaha adalah seseorang yang siap untuk mengambil risiko - risiko dan dia berbeda dengan seorang yang mensuplai modal dengan berharap keuntungan yang tetap. Para wirausaha juga dipandang berbeda dengan kapitalis (pemilik modal) yang mensupai modal dan bersamaan dengan itu mengeksploitasi pihak yang terlibat. 5

Dalam agama Islam entrepreneur atau wirausaha adalah sangat dianjurkan, karena ajaran Islam sangat menghargai orang yang bekerja. Entrepreneur muslim sejatinya adalah wirausaha yang menjalankan roda bisnisnya berdasarkan nilai - nilai yang ada dalam ajaran Islam. Nilai-nilai tersebut merupakan perwujudan dari beberapa prinsip yaitu, prinsip tauhid, keadilan, menjauhi dari hal - hal yang haram, memperhatikan kemaslahatan, dan membiasakan prinsip ta'awun (tolong menolong). Prinsip - prinsip ekonomi Islam tersebut akan dibahas lebih rinci dalam tulisan ini.

\section{Prinsip-prinsip Islamic Entrepreneurship}

1. Prinsip Tauhid

\footnotetext{
4 Pusat Bahasa Departemen Pendidikan Nasional, Kamus Besar Bahasa Indonesia, Ke-3. (Jakarta: Balai Pustaka, 2003).1273

${ }^{5}$ Z Heflin Frinces, "Pentingnya Profesi Wirausaha Di Indonesia," Jurnal Ekonomi \& Pendidikan Vol.7 No.1(n.d.): 44.
} 
Asal makna tauhid adalah keyakinan bahwa Allah itu satu, tidak ada sekutu bagi-Nya. Ilmu tauhid sendiri adalah ilmu yang membahas tentang ketuhanan dan sifat-sifat wajib bagi Allah. ${ }^{6}$ Dalam konteks ekonomi, prinsip tauhid dimaknai sebagai sebuah spirit dalam melakukan suatu tindakan ekonomi harus bergantung pada Allah. Prinsip tauhid sendiri adalah dasar dari segala perbuatan manusia, keyakinan atau pandangan hidup seperti ini akan melahirkan aktifitas yang memiliki akuntabilitas ketuhanan, sehingga segala bentuk aktifitas ekonomi diharapkan akan membentuk integritas sesuai prinsip-prinsip syariah. Dalam ekonomi Islam prinsip tauhid menjadi prinsip utama yang akan menopang prinsip- prinsip lainnya. Kesadaran akan tauhid akan membawa keyakinan bahwa segala bentuk aktifitas apa pun didunia ini akan dimintai pertanggungjawaban oleh sang kholik, sehingga seorang pelaku ekonomi tidak mengejar keuntungan materi semata.

Secara faktual, seperti yang ditulis Quraish Sihab dalam Mursal, sebagian manusia sangat sulit untuk mengendalikan keinginannya mendapatkan keuntungan yang banyak, meskipun pada waktu yang sama menganiaya manusia lain. Jika spirit tauhid tidak tertanam sebagai moral para pelaku ekonomi maka akan banyak bentuk penindasan dan eksploitasi dalam ekonomi. ${ }^{7}$ Dalam kondisi seperti ini menurut Qurais Sihab dalam Mursal, negara diperbolehkan mengintervensi untuk mengontrol kegiatan ekonomi demi kemaslahatan bersama. Seperti mengendalikan harga-harga bahan pokok agar tidak melejit dan menindas masyarakat miskin.

2. Prinsip Keadilan

Keadilan adalah salah satu prinsip yang diajarkan dalam Islam, menurut kamus bahasa Indonesia "adil", berarti sama

6 Firdaus, "Konsep Ketuhanan Dalam Al-Qur'an," Jurnal Diskursus Islam Vol.3 No.1 (2015): 103.

${ }^{7}$ Mursal, "Implementasi Prinsip-Prinsip Ekonomi Syariah, Alternative Mewujudkan Kesejahteraan Berkeadilan," Jurnal Prespektif Ekonomi Darussalam Vol. 1, No.1 (2015): 75. 
berat, tidak berat sebelah, berpihak kepada yang benar dan sepatutnya. ${ }^{8}$ Dalam terminology fikih, adil adalah menempatkan sesuatu pada tempatnya, memberikan sesuatu hanya pada yang berhak dan melakukan sesuatu sesuai posisinya. ${ }^{9}$ Dalam ekonomi Islam implementasi keadilan ada pada larangan riba, maisir, gharar dan haram.

a. Riba

Riba merupakan suatu tantangan yang menggiurkan dalam dunia bisnis, kata riba dari segi bahasa berarti "kelebihan", dalam Al-Qur'an ditemukan kata riba terulang sebanyak delapan kali, terdapat dalam empat surat, yaitu Al Baqarah, Ali Imron, An Nisa' dan Ar Rum. ${ }^{10}$ Islam melarang riba dengan segala jenisnya karena bertentangan dengan, prinsip kemanusiaan, persaudaraan dan kasih sayang. Pengharaman riba merupakan salah satu penghapusan praktik ekonomi yang tidak berkeadilan dan menimbulkan kedloliman karena bagian dari eksploitasi manusia.

Berdasarkan transaksinya, riba dibagi menjadi dua yaitu; riba utang piutang dan riba jual beli. Riba utang piutang terbagi menjadi dua lagi yaitu riba qard dan riba jahiliyah. Riba qard adalah suatu manfaat atau kelebihan tertentu yang disyaratkan terhadap orang yang berhutang. Sedangkan riba jahiliyah adalah merupakan utang yang harus dibayar lebih dari jumlah pokoknya, karena si peminjam tidak mampu membayar hutangnya pada waktu yang telah ditentukan. Riba jual beli jual beli terbagi menjadi dua, riba fadl dan riba nasi'ah, riba fadl adalah pertukaran barang dengan barang sejenis tetapi kadarnya berbeda. Riba nasi'ah adalah pertukaran antara barang dengan barang yang sejenis secara tangguh, riba ini muncul karena

\footnotetext{
${ }^{8}$ Pusat Bahasa Departemen Pendidikan Nasional, Kamus Besar Bahasa Indonesia, n.d. 26

${ }_{9}^{9}$ Mursal, "Implementasi Prinsip-Prinsip Ekonomi Syariah, Alternative Mewujudkan Kesejahteraan Berkeadilan."78

${ }^{10}$ Quraish Shihab, Membumikan Al-Qur'an (Bandung: Mizan, 1994).258
} 
adanya perbedaan, perubahan, atau tambahan antara yang diserakan saat ini, dengan yang diserahkan kemudian. ${ }^{11}$

b. Maisir

Perkataan maisir, berasal dari kata yasara atau yusr yang bermakna "mudah", atau yasar yang bermakna "kekayaan". Secara terminologis maisir berarti bentuk permainan yang mengandung unsur taruhan, pihak yang memenangkan permainan berhak memenangkan taruhan. ${ }^{12}$ Pada saat ini banyak sekali tawaran investasi yang mengandung unsur judi, misalnya, reksa dana. Kemungkinan keuntungan dalam bisnis sektor ini mengandalkan ketidakpastian atau untung-untungan. Di mana seseorang yang akan memutuskan membeli atau menjual saham tertentu biasanya didasarkan pada perkiraan atau harapan bahwa saham tersebut akan naik atau turun pada saat tertentu. Saat ini untuk memberi alternatif kepada investor muslim, yang ingin menghindari unsur maysir, yang dilarang Islam, sudah ada Reksa Dana Syariah dengan karakteristik berbeda dengan Reksa Dana Konvensional, meskipun banyak yang mensinyalir belum bebas total dari unsur spekulasi, tatapi paling tidak sahamnya diinvestasikan pada perusahaan yang berbasis syariah.

c. Gharar

Ibnu Taimiyyah dalam Antonio, menyatakan gharar adalah sesuatu yang tidak jelas hasilnya (majhul alaqibah), sedangkan menurut Syekh As-sa'di gharar adalah mukhatarah atau taruhan dan jahalah atau ketidak jelasan. ${ }^{13}$ Berdasarkan penjelasan ini gharar dapat difahami sebagai transaksi yang tidak jelas baik dalam akad, maupun barang yang diperjualbelikan. Gharar dapat pula dikatakan sebagai transaksi mu'amalah yang mengandung ketidakjelasan tentang adanya komoditas

${ }^{11}$ Antonio, Ensiklopedi Bisnis \& Kewirausahaan, n.d.n.149

12 Ibid.155

13 Ibid.151 
yang menjadi obyek akad, ketidakjelasan akibat bahaya yang mengancam akan adanya kerugian pada salah satu pihak yang bertransaksi atau bahkan keduanya. Ditinjau dari isi kandungannya bentuk-bentuk transaksi gharar menurut Abdullaah Muslih dalam Hosen, terbagi menjadi tiga bagian yaitu:

1) Jual beli barang yang belum ada ( $m a^{\prime} \mathrm{dum}$ )

Jual beli dengan cara penjual belum mampu menyerahkan obyek yang dijual pada saat terjadinya akad. Contohnya jual beli hewan ternak yang masi dalam kandungan induknya.

2) Jual beli barang yang belum jelas (majhul)

Menjual barang yang belum jelas, baik ketidakjelasan jenis dan sifatnya maupun ketidakjelasan ukurannya.

3) Jual beli barang yang tidak bisa diserahterimakan, contohnya jual beli burung yang sedang terbang, jual beli mobil yang masi hilang. ${ }^{14}$

d. Haram

Haram adalah sesuatu yang dilarang oleh Allah apabila dilakukan mendapat dosa, didalam aktifitas ekonomi (muamalah) pada hakekatnya semua adalah boleh (mubah) kecuali ada dalil yang mengharamkanya. Hal ini kebalikkan dari perkara ibadah, semua ibadah pada hakekatnya adalah haram kecuali adanya perintah untuk melakukannya. Oleh karena itu harus kita ketahui apa apa yang menyebabkan aktifitas ekonomi menjadi haram. Sebab keharaman suatu aktifitas ekonomi dapat dikelompokkan menjadi tiga:

1) Haram li dzatihi, (haram karena zatnya), sesuatu yang diharamkan Allah karena zatnya, contohnya daging babi, bangkai dan darah. Transaksi menjadi haram karena yang ditransaksikan adalah benda benda yang menurut zatnya adalah haram, seperti jual beli

${ }^{14}$ Nadratuzzaman Hosen, "Analisis Bentuk Gharar Dalam Transaksi Ekonomi," Jurnal Al-iqtishad Vol.1 No.1 (n.d.): 57. 
makanan dengan bahan daging babi, jual beli minuman khamer termasuk juga narkoba.

2) Haram li ghairihi, (haram karena sebab diluar zatnya), transaksi hal - hal yang halal karena zatnya akan menjadi haram apabila ada faktor lain yang dilarang. Seperti adanya unsur riba, maisir dan gharar.

3) Haram karena akad transaksi tidak sempurna, seperti tidak terpenuhi rukun dan syaratnya, dalam suatu akad atau transaksi terdapat rukun dan syarat yang harus dipenuhi. Ketidak sempurnaan rukun dan syarat tersebut membatalkan transaksi.

3. Prinsip Maslahat

Kata maslahat dalam kamus bahasa Indonesia memiliki arti, sesuatu yang mendatangkan kebaikan, keselamatan, faedah atau guna. ${ }^{15}$ Maslahat juga dapat diartikan dengan mengambil manfaat dan menolak kemudzaratan atau bahaya. Sedangkan maslahat menurut ulama fiqih adalah suatu hukum yang ditetapkan untuk memelihara lima hal yaitu agama, jiwa, akal, keturunan dan harta. Hakekat maslahat adalah segala bentuk kebaikan dan manfaat yang bersifat menyeluruh baik untuk kebaikan ukhrowi maupun duniawi, materiel maupun sprituil, individu maupu sosial.

Aktifitas ekonomi dipandang sebagai sebuah maslahat apa bila memenuhi dua hal yaitu, kehalalan yang berarti ketaatan dalam memenuhi ketentuan Allah dan bermanfaat serta membawa kebaikan dalam segala aspek secara integral, serta tidak menimbulkan kemudzaratan. Dalam konteks pembinaan dan pengembangan ekonomi prinsip maslahat memiliki kedudukan yang sangat penting, karena dalam prinsip muamalah semua bentuk muamalah diperbolehkan kecuali hal-hal yang telah dilarang, berbeda dengan ibadah segala bentuk ibadah adalah haram kecuali ibadah yang telah dicontohkan ole nabi Muhamad SAW. Dalam rangka memperhatikan kemaslahatan inilah dalam

15 Pusat Bahasa Departemen Pendidikan Nasional, Kamus Besar Bahasa Indonesia. 720 
sejarah pengelolahan ekonomi Umar Bin Al Khatab pernah berijtihad yang menimbulkan kontroversi dengan tidak membagikan zakat kepada golongan mualaf, alasan Umar tidak memberikan zakat kepada mualaf adalah karena mereka sudah bukan mualaf lagi, karena dalam waktu yang lama ke imanan. mereka sudah kuat. ${ }^{16}$

4. Prinsip Ta'awun (tolong menolong)

Ta'awun atau tolong menolong adalah salah satu prinsip dasar dalam ekonomi Islam, salah satu pengaplikasian dalam prinsip ini adalah kewajiban zakat bagi umat Islam, berbeda dengan ekonomi kapitalis yang menghendaki adanya kebebasan seluas luasnya bagi individu untuk melakukan aktifitas ekonomi tanpa campur tangan pemerintah, berbeda juga dengan prinsip sosialis komunis yang menginginkan kesejahteraan secara merata dengan negara sebagai penguasa segala aset, system ekonomi Islam berada diantara keduanya.

Islam mengakui kepemilikan pribadi tetapi Islam tidak memperbolehkan ekpoitasi terhadap sesama, dalam Islam ada kewajiban zakat, juga ada anjuran sedekah sebagai bentuk distribusi kekayaan, karena dalam Islam tidak diperbolehkan harta hanya berputar pada sekelompok orang saja. Dengan prinsip ta'awun (tolong menolong), Islam menginginkan kesejahteraan yang berkeadilan karena ada hak fakir miskin dalam harta orang kaya, sehingga kesenjangan ekonomi dapat di minimalisir.

\section{Entrepreneur Muslim, Koneksi dan Komunitas Bisnis}

Tidak dapat dipungkiri bahwa untuk membangun koneksi dan komunitas adalah suatu hal yang sangat urgen dalam dunia bisnis, tanpa kemampuan membangun dua hal diatas, bisnis dapat dipastikan tidak akan dapat berkembang dengan pesat. Pada tulisan ini akan dibahas dua hal tersebut

\footnotetext{
16 Yusuf Al-Qardhawi, Fiqih Maqasid Syari'ah (Jakarta: Pustaka Kautsar, 2007).103
} 
yaitu, tentang koneksi atau connection atau networking, dan tentang komunitas bisnis.

Koneksi berasal dari bahasa inggris connection memiliki arti yang sama dengan network atau networking yang memiliki arti jaringan. Networking adalah kegiatan sosial ekonomi yang berupa mengenali, menciptakan, atau bertindak untuk menemukan peluang bisnis. Networking bukan merupakan suatu teori tetapi merupakan sesuatu hal yang sangat praktis dan penting dipelajari bagi Entrepreneur. Sedangkan, komunitas dalam kamus bahasa Indonesia diartikan sebagai kelompok atau organisasi masyarakat yang hidup dan berinteraksi satu sama lain dalam suatu daerah tertentu. ${ }^{17}$ Dalam pengertian sosiologis komunitas terbentuk atas kesatuan wilayah, atau kedekatan wilayah, komunitas juga dapat terbentuk karena kekerabatan, kepentingan yang sama dan keterikatan karena saling membutuhkan. ${ }^{18}$ Sebagai entrepreneur muslim kemampuan membangun komunitas juga sangat menentukan keberhasilan suatu bisnis, karena dengan memiliki komunitas seorang pengusaha dapat saling membantu dalam proses pengembangan usaha. Selain kemampuan membangun komunitas, seorang entrepreneur juga dituntut memiliki kemampuan dalam membangun jaringan usaha, karena kemampuan membangun komunitas dan koneksi bisnis adalah dua hal yang dapat menopang kesuksesan suatu usaha.

Sebagai entrepreneur muslim adalah suatu keharusan untuk memiliki kemampuan dalam membangun relasi bisnis, karena tanpa kekuatan jaringan atau relasi bangunan bisnis tidak akan berkembang secara maksimal. Hal ini termasuk salah satu ajaran yang harus diamalkan dalam mencontoh prilaku bisnis nabi Muhamad SAW, yaitu menyambung

\footnotetext{
17 Pusat Bahasa Departemen Pendidikan Nasional, Kamus Besar Bahasa Indonesia. 586

18 Syayuti, "Pemerintah Pasar Dan Komunitas Faktor Utama Dalam Pengembangan Agribisnis Di Pedesaan," Forum Penelitian Agro Ekonomi Vol. 22 No (n.d.): 58.
} 
silaturahmi. Dalam membangun jaringan atau koneksi bisnis ada beberapa hal yang harus diperhatikan dengan meneladani sifat - sifat dan karakter rasulullah, sifat - sifat tersebut adalah, siddiq, amanah, fathanah dan tabligh. ${ }^{19}$

Seorang entrepreneur harus memegang prinsip siddiq, yang berarti "jujur", atau "benar", prinsip ini adalah prinsip yang sangat penting diterapkan dengan sungguh - sungguh dalam dunia usaha, sekali berkata dan berbuat tidak jujur maka rekan bisnis baik pelanggan mau pun pemasok barang akan menjauhi pebisnis yang tidak jujur atau tidak mampu berkata benar. Kejujuran dapat di artikan dalam beberapa hal yaitu, entrepreneur muslim harus mampu menepati janji yang telah disepakati, tidak menyembunyikan cacat suatu barang yang akan ditransaksikan, tidak mengelabuhi harga pasar (asymmetric information).

Prinsip yang kedua adalah "amanah", amanah artinya dapat dipercaya, dalam kontek ekonomi amanah dapat diartikan mampu menyampaikan informasi tentang barang atau jasa yang akan ditransaksikan dengan jelas tanpa ada yang ditutup tutupi sehingga merugikan para pelanggan. Menerapkan sifat amanah dalam dunia bisnis dapat mendatangkan keuntungan, karena baik pelanggan maupun mitra bisnis akan merasa tenang dalam melakukan transaksi dengan rekan bisnis yang dapat dapat dipercaya dalam artian mampu memegang amanah dengan teguh. Prinsip amanah dalam bertransaksi dapat tercermin dengan, tidak mengurangi sesuatu yang disetujui, tidak menambah sesuatu yang disepakati dan memberikan sesuatu sesuai pesanan.

Prinsip yang ketiga adalah "fathanah", atau cerdas, seorang entrepreneur harus cerdas, sehingga mampu menjalankan peran dan bertanggungjawab terhadap usaha yang dijalankannya. Di dalam dunia usaha yang kompetitif seperti saat ini kecerdasan dalam berinovasi sangat diperlukan,

${ }^{19}$ Syafi'i Antonio, Bisnis \& Kewirausahaan, n.d.62 
pengusaha yang stagnan tidak mampu berinovasi mengikuti perkembangan zaman akan tertinggal.

Prinsip fathanah selanjutnya tercermin dari kemampuan dalam menjaga profesionalitas dan pelayanan, kemampuan dalam mengantisipasi perubahan yang terjadi dipasar, baik yang berhubungan dengan produk, tehknologi persaingan harga maupun kreatifitas dan inovasi. Kecakapan selanjutnya adalah kemampuan dalam antisipasi dengan kemanpuan mengantisipasi atau dalam bahasa ekonominya manajemen risiko entrepreneur dapat bertahan dan eksis dalam dunia usaha.

Prinsip yang terahir adalah tabligh atau kemampuan menyampaikan, kemampuan menyampaikan dalam konteks ekonomi adalah kemampuan menyampaikan informasi tentang produk yang dimiliki sehingga produk tersebut dikenal dan kemudian diminati oleh masyarakat. Kemampuan menyampaikan informasi produk untuk saat ini dapat dilakukan dengan bekerjasama dengan perusahaan periklanan. Seorang entrepreneur muslim yang mampu memegang keempat sifat dasar Rasulullah dalam berbisnis, maka akan mampu mempertahankan dan mengembangkan bisnisnya.

\section{Sejarah Berdirinya Komunitas Entrepreneur Sari Bumi}

Penduduk desa Brangsi kabupaten Lamongan awalnya dikenal sebagai warga perantau keluar negeri, mereka rata-rata sebagai perantau ke Malaysia dan Singapura, seperti halnya penduduk desa tetangganya yang lain. Tetapi warga desa Brangsi merantau hanya untuk mencari modal, setelah mereka memiliki modal mereka akan kembali ke Indonesia untuk membuka usaha, salah satu usaha yang ditekuni mayoritas penduduk desa Brangsi adalah membuka toko yang menjual bahan-bahan bangunan. Penduduk desa Brangsi yang melakukan usaha dibidang penjualan bahan-bahan bangunan ada beberapa komunitas, yang pertama adalah komunitas Sinar Jaya atau Nur Jaya, komunitas ini memberi nama toko mereka dengan nama Sinar Jaya, jadi apabila ada toko bahan bangunan dengan nama Sinar Jaya itu dapat dipastikan adalah milik

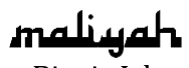


warga desa Brangsi Lamongan. ${ }^{20}$ Komunitas selanjutnya adalah komunitas Sari Bumi, komunitas toko bahan bangunan Sari bumi dirintis oleh salah seorang perantau dari desa Brangsi Lamongan yang bernama Haji Muntaham.

Nama usaha Sari Bumi terbentuk berawal dari ide tiga orang yaitu, Haji Muntaham, Haji Marjono dan Haji Suradji, ketiganya berasal dari desa Brangsi Lamongan, mereka bertiga berinisiatif melakukan suatu usaha bersama. Pemberian nama dilakukan melalui perenungan yang panjang dengan disertai solat tahajud dan puasa sunnah agar mendapat petunjuk dan keberkahan, pada ahirnya mereka memberi nama "Sari Bumi " untuk usaha bersama mereka.

Pada mulanya usaha ini bergerak di bidang produksi batu kapur di daerah gunung kapur Lamongan. Kemudian mereka bertiga memisahkan diri untuk menjalani bisnis secara mandiri. ${ }^{21}$ Setelah memutuskan untuk usaha sendiri pada tahun 1982 Haji Muntaham hijrah ke Surabaya, beliau memulai merintis usaha penjualan bahan-bahan bangunan dengan mengontrak rumah di daerah rungkut industry. Haji Muntaham sosok yang penuh semangat, semangat beliau untuk selalu bekerja keras dan menjadi orang yang memiliki kemampuan secara ekonomi tumbuh ketika beliau masih muda dan mendapati orang tua beliau sedang sakit, Haji Muntaham muda diminta untuk menjemput kakak beliau yang sudah menikah dan kakak beliau menikah dengan perempuan yang memiliki kekayaan lebih, ketika Haji Muntaham datang untuk menjemput kakaknya dan mengabarkan orang tuanya sedang sakit istri kakaknya tidak berkenan dan menganggap Haji muntaham akan merepotkan secara financial, dari sinilah beliau termotivasi untuk menjadi orang berkecukupan secara financial agar bisa menolong orang yang membutuhkan, hal ini diceritakan oleh Haji Anas Asrofi.

\footnotetext{
20 Syamil, "wawancara”, Toko Bangunan Karya Gemini Tanggulangin, 26 April 2018.

${ }^{21}$ Siti Muthaharah, “wawancara”, Sari Bumi Ngampelsari, 19 April 2018.
} 
Karena sikap yang peduli kepada para kerabatnya inilah, awal terbentuknya komunitas usaha Sari Bumi, almarhum Haji Muntaham melibatkan kerabatnya baik baik saudara kemenakan, adik maupun sepupunya dalam usaha toko bangunannya, setelah mereka mampu mereka dipersilakan membuka toko sendiri dengan modal bantuan tanpa bunga dari Haji Muntaham. Demikian seterusnya saudaranya yang telah ditolong dan mampu mandiri dengan membuka toko sendiri juga menolong kerabat mereka, sehingga banyak sekali toko bahan bangunan dengan nama Sari Bumi di beberapa kabupaten Lamongan, Surabaya, Gresik dan Sidoarjo, tetapi mayoritas toko Sari Bumi yang menjual bahan bangunan dari keluarga dan kerabat almarhum Haji Muntaham berada di kabupaten Sidoarjo.

Awal mula berkembangnya komunitas Sari Bumi dengan menerapkan prinsip ta'awun (tolong menolong), selain melibatkan para kerabatnya dalam menjalankan usahanya almarhum Haji Muntaham juga memberikan bantuan modal tanpa bunga kepada saudara kemenakan, setelah usaha berjalan saudara kemenakan tersebut juga diminta memberi bantuan modal kepada kerabat yang lain. ${ }^{22}$ Selain prinsip tolong menolong, untuk menjaga ukhuwa, dalam komunitas Sari Bumi juga ada pertemuan rutin, yaitu arisan keluarga, pertemuan arisan keluarga ini berfungsi sebagai pertemuan bisnis dan bertemuan ta'lim atau pertemuan untuk memperdalam pengetahuan agama. Sebagai pertemuan bisnis dalam arisan keluarga ini juga difungsikan untuk evaluasi bersama, adakah anggota komunitas yang sedang mengalami kesulitan masalah keuangan atau kebangkrutan, sehingga keluarga tersebut berhak menerima arisan tersebut tanpa diundi sebagaimana arisan pada umumnya. ${ }^{23}$ Selain pertemuan rutin yang sudah terjadwal setiap bulannya Almarhum Haji

22 Abdul Karim, "wawancara", Toko Sari Bumi Raya Kav DPR A II Sidoklumpuk, 24 April 2018.

23 Ida Mufida, "wawancara", Toko Sari Bumi Raya Kav DPR A II Sidoklumpuk, 24 April 2018 
muntaham semasa hidupnya rajin sekali bersilaturami mengunjungi para anggota pengusaha Sari Bumi yang masi muda, sekedar menanyakan kabar, membimbing, memotivasi dan memberi solusi ketika anggota tersebut mengalami kesulitan dalam mengembangkan usahanya.

Besaran arisan sebagai media silaturahmi tidak bersifat tetap tetapi mengalami kenaikan sesuai zamannya pada awalnya arisan tersebut hanya berupa satu kilo cat emco, kemudian seharga sepeda motor pada waktu itu tetapi dikumpulkan dalam bentuk nominal uang, misalnya harga sepeda motor pada waktu itu 12 (dua belas) juta, 12 juta tersebut dibagi sejumlah anggota arisan. Untuk saat ini nominal arisan komunitas Sari Bumi sudah berkembang seharga mobil pada saat ini. ${ }^{24}$ Dengan prinsip ta'awun, saling menjaga silaturahmi dan memberi tauladan, inilah komunitas pengusaha Sari Bumi menjadi besar, untuk saat ini ada 158 (seratus lima puluh delapan) toko bahan bangunan yang menyebar di Kabupaten Sidoarjo. ${ }^{25}$

\section{Peran Entrepreneur Sari Bumi dalam Membangun Koneksi Bisnis.}

Berdasarkan hasil penelitian komunitas usaha dalam bidang penjualan bahan-bahan bangunan yang dikenal dimasyarakat dengan nama Sari Bumi memulai usaha mereka pada tahun 1982. Pada awalnya usaha ini ditekuni oleh satu keluarga kemudian dalam perjalanan waktu usaha penjualan bahan-bahan bangunan ini menjadi familiar dimasyarakat karena berdasarkan hasil penelitian telah ada 158 toko bahan bangunan yang bernama Sari Bumi di kabupaten Sidoarjo, dan dimiliki oleh 80 (delapan puluh) keluarga. Dalam penelitian ini yang ingin dianalisis adalah bagaimana peran para entrepreneur Sari Bumi dalam membangun koneksi dan komunitas bisnis sehingga bisnis tersebut bisa berkembang

24 Ida Mufida, "wawancara", Toko Sari Bumi Raya Kav DPR A II Sidoklumpuk, 24 April 2018

${ }^{25}$ Data Arisan anggota Sari Bumi 
dan berkelanjutan sampai saat ini, berdasarkan data hasil penelitian ada beberapa peran yang dilakukan oleh para entrepreneur Sari Bumi dalam membangun koneksi dan komunitas bisnis dan menjaga keberlangsungan usaha mereka di masyarakat, peran yang dilakukan oleh para entrepreneur Sari Bumi dalam membangun koneksi bisnis adalah :

1. Selalu menjalin hubungan baik dan menghargai orang lain.

Dalam dunia bisnis para entrepreneur Sari Bumi dikenal selalu menjaga hubungan baik dan menghargai orang lain, hal ini diungkapkan oleh bapak Syamil salah satu responden dalam penelitian ini,

"Para pengusaha Sari Bumi itu orangnya kaya-kaya, rata-rata mereka memiliki toko bangunan lebih dari satu, pertama sekali diajak gabung dalam komunitas pengusaha Sari Bumi jujur saya agak minder, ada perasaan kurang enak takutnya mereka merendahkan kami karena kami baru merintis usaha dan belum punya apa-apa, tetapi setelah gabung ternyata mereka orang-orang baik, ramah, enak dalam berkomunikasi dan yang penting mereka bersedia berbagi informasi tentang dunia usaha, kami sangat beruntung sekali bergabung dalam komunitas Sari Bumi karena banyak informasi tentang usaha yang dapat kami terima". ${ }^{26}$

2. Menjaga reputasi.

Dalam buku yang ditulis oleh Jeffrey Wayne Meshel (1957) mengatakan, jagalah reputasi, karena reputasi akan diingat orang sampai ke liang kubur, nampaknya hal inilah yang selalu dipraktikkan oleh para pengusaha Sari Bumi. ${ }^{27}$ Para pengusaha Sari Bumi benar-benar serius dalam menjaga reputasi perusahaan mereka sehingga nama Sari Bumi dikenal sebagai toko milik pengusaha muslim yang dapat dipercaya baik oleh supplier maupun pelanggan. Hal ini

\footnotetext{
26 Syamil, "wawancara", Toko Bangunan Karya Gemini Tanggulangin, 26 April 2018.

27 Jeffrey W Meshel, Secrets of Master Networker: 35 Strategi Membangun

Relasi Bisnis Sehari-Hari (Jakarta: PT. Bhuana Ilmu Populer, 2005).29
} 
diungkapkan oleh ibu Hajjah Siti Muthahara salah satu responden dalam penelitian ini,

"Alhamdulillah toko Sari Bumi sangat dipercaya oleh para supplier, hal ini saya rasakan sendiri ketika usaha kami sedang dalam kondisi yang menurun, beberapa suppier mempercayai kami dan bersedia untuk memberi tenggang waktu pembayaran. Berbeda dengan toko yang bukan Sari Bumi rata-rata jika mereka mengalami kebangkrutan sulit untuk bangkit kembali karena tidak mendapat dukungan seperti toko Sari Bumi". 28

Hal yang sama juga disampaikan oleh Haji Anas Asrofi, "Nama Sari Bumi ini sudah dikenal baik dimasyarakat, terutama oleh para supplier bahan bangunan, hal ini terbukti ketika kami melakukan family gathering keluarga besar Sari Bumi kemarin, kami mendapat banyak bantuan, baik yang berupa dana maupun yang berbentuk lain. Sehingga acara family gathering dapat terlaksana dengan sukses". 29

3. Selalu berbagi dengan relasi bisnis, baik tentang informasi maupun hal lain yang dapat saling menguntungkan dalam hubungan bisnis.

Selalu berbagi dengan relasi bisnis ini juga senantiasa dilakukan oleh para entrepreneur Sari Bumi, salah satu contohnya adalah kemurahan hati dan saling tolong menolong yang mereka praktikkan dalam kehidupan seharihari, baik dalam hubungan bisnis maupun hubungan kekeluargaan dan kemasyarakatan. Dalam hubungan bisnis misalnya mereka saling memberi support pendanaan jika salah satu anggota entrepreneur Sari Bumi mengalami kesulitan secara financial untuk melangsungkan bisnis mereka. Hal ini mereka lakukan dengan membentuk arisan keluarga dengan model perolehannya tidak mereka undi seperti arisan yang dilakukan masyarakat pada umumnya, tetapi dengan mengevaluasi anggota mereka yang sangat

${ }^{28}$ Siti Muthaharah, "wawancara”, Sari Bumi Ngampelsari, 19 April 2018.

${ }^{29}$ Anas Asrofi, "wawancara", Kantor Sari Bumi Bangunan, 10 April 2018. 
membutuhkan bantuan sebagai perputaran modal dalam usaha mereka.

4. Membangun hubungan baik melalui komunikasi yang effektif.

Satu hal yang paling mendasar dalam menjalin hubungan bisnis adalah membangun komunikasi yang baik, membangun komunikasi yang baik dan effektif dapat dilakukan melalui beberapa model, dapat dengan membentuk wadah pertemuan seperti yang dilakukan oleh entrepreneur Sari Bumi, dapat juga melalui hubungan personal sehari-hari. Dalam upaya membangun hubungan baik dengan relasi bisnis entrepreneur Sari Bumi membentuk wadah pertemuan, ada dua wadah pertemuan yang mereka bentuk, yang pertama adalah pertemuan internal keluarga besar entrepreneur Sari Bumi yang mereka kemas dengan arisan keluarga dan ta'lim muta'alim, pertemuan internal keluarga ini mereka lakukan dua kali dalam sebulan. Yang kedua adalah pertemuan dengan seluruh pemilik toko bahan bangunan baik pemilik toko Sari Bumi maupun bukan Sari bumi, pertemuan komunitas ini bernama Ar-rihla. Dua kelompok pertemuan tersebut salah satu tujuannya adalah membangun komunikasi yang effektif sesame pemilik toko bahan bangunan dikabupaten Sidoarjo. Selain membentuk wadah pertemuan entrepreneur Sari Bumi juga selalu membangun komunikasi yang baik dengan supplier juga pelanggan mereka.

5. Selalu menjaga performa dan persepsi diri sebagai entrepreneur.

Selalu menjaga performa dan persepsi diri sebagai pengusaha yang dapat dipercaya adalah upaya yang dilakukan oleh entrepreneur Sari Bumi. Salah satunya seperti yang disampaikan oleh Haji Anas Asrofi ketika wawancara dengan peneliti, dalam menjaga keberlangsungan usaha yang dirintis ayah kandungnya Haji Anas Asrofi melakukan beberapa upaya agar toko Sari Bumi yang mereka miliki mampu bersaing dalam dunia usaha yang selalu dinamis. Salah satu upaya yang dilakukan adalah dengan merubah 
system administrasi yang dulu manual dengan system informasi yang berbasis aplikasi komputer, berinovasi dengan mendirikan perusahaan supplier untuk menghindari ketergantungan dengan pihak lain. Hal ini dilakukan untuk menjaga performa perusahaan baik dimata masyarakat sebagai pelanggan maupun dimata relasi bisnis.

\section{Peran Entrepreneur Sari Bumi dalam Membangun Komunitas Bisnis.}

Selain upaya membangun koneksi bisnis seperti yang diuraikan diatas, entrepreneur Sari Bumi juga membangun komunitas bisnis untuk menjaga keberlangsungan usahanya dimasyarakat, adapun peran entrepreneur Sari Bumi dalam membangun komunitas bisnis adalah sebagai berikut:

1. Membuka lapangan pekerjaan dan sumber penghasilan.

Para entrepreneur Sari Bumi berperan dalam membuka lapangan pekerjaan khususnya bagi kerabat yang terlibat dalam bisnis pada toko bahan bangunan tersebut, dengan adanya lapangan pekerjaan maka akan membuka sumber penghasilan. Dari hasil penelitian walaupun rata-rata para pengusaha Sari Bumi telah menyelesaikan studi mereka pada jenjang pendidikan tingkat stata satu (S1), ada juga S2 tetapi minat berwirausaha mereka masi cukup tinggi. Terbukti dengan berbagai latar belakang pendidikan mereka tidak menyurutkan minat mereka untuk berwirausaha dengan membuka toko bahan bangunan, bagi mereka profesi apa pun itu adalah sebagai ladang amal, sedangkan untuk mencari penghasilan, mereka lebih suka berwirausaha. Hal ini seperti yang disampaikan oleh salah satu responden dalam penelitian ini yaitu ibu Ida mufidah, ibu Ida Mufida mengatakan bahwa profesi apapun itu sebagai ibadah, tetapi untuk mencari penghasilan kami lebih merasa nyaman dengan berwirausaha. Ibu Ida Mufidah memiliki putra dan juga adik kandung yang berprofesi sebagai dokter, tetapi baik putra maupun adik kandungnya juga memiliki toko bahan bangunan.

2. Menciptakan pribadi yang mandiri secara financial. 
Salah satu manfaat berwirausaha adalah menjadi pribadi yang mandiri secara financial, karena dengan berwirausaha tidak tergantung kepada orang lain, dengan berwirausaha dapat menentukan segala sesuatu secara mandiri. Dengan berwirausaha kesempatan sukses terbuka sangat lebar karena semua hal dapat ditentukan secara mandiri, mulai dari target, cara berinovasi semua tergantung pada kemauan dan kemampuan serta kerja keras sendiri, hal ini terbukti dengan bervareasinya kondisi ekonomi para entrepreneur Sari Bumi. Salah satu indikasi yang terlihat adalah berbedaan kepemilikan toko bangunan sebagai tempat usaha mereka, ada yang memiliki hanya satu toko bangunan, ada yang memiliki dua, tiga dan paling banyak memiliki 14 toko bangunan. Berdasarkan hasil penelitian semakin banyak jumlah toko yang dimiliki dan dikelolah oleh entrepreneur Sari Bumi, semakin baik juga kemampuan secara financialnya. Hal ini terindikasi dari beberapa aset yang dimiliki, tingkat pendidikan putra putrinya dan fasilitas hidup lainnya. Dengan berwirausaha memiliki kebebasan mengatur waktu. Karena memiliki kebebasan mengatur waktu para entrepreneur Sari Bumi banyak memenfaatkan waktu mereka untuk hal- hal yang positif, seperti mengelolah yayasan sosial yang mereka miliki dan aktif dibeberapa organisasi masyarakat dan keagamaan.

3. Mendorong dan melatih tumbuhnya jiwa entrepreneur.

Para entrepreneur Sari Bumi sangat berperan dalam mendorong tumbuhnya jiwa entrepreneur khususnya pada internal keluarga, dan secara umum pada masyarakat yang berminat menekuni bisnis pada bidang penjualan bahanbahan bangunan. Karena jiwa entrepreneur perlu dilatih dan dikembangkan maka diperlukan kepedulian untuk berbagi pengetahuan dan pengalaman seperti yang dilakukan oleh entrepreneur Sari Bumi.

4. Membangun generasi yang berjiwa entrepreneur

Para entrepreneur Sari Bumi sangat berperan dalam membangun generasi yang berjiwa entrepreneur, hal ini dilakukan untuk memperluas komunitas bisnis dan menjaga 
keberlanjutan usaha. Untuk menjaga keberlanjutan usaha dan memperluas komunitas bisnis, para entrepreneur Sari Bumi menerapkan system pengkaderan, mulai yang dilakukan oleh perintis usaha tersebut yaitu Haji Muntaham, beliau melibatkan beberapa ponakkan, sepupu juga adiknya dalam menjalankan usahanya, mereka adalah bapak Ahmad Sya'i, bapak Abdul Karim, bapak Ahmad Khoiri, ibu Siti Muthahara. Mereka tersebut pada awalnya dilibatkan sebagai karyawan pada toko Sari Bumi milik Haji Muntaham. Seperti yang disampaikan bapak Abdul Karim dalam wawancara. ${ }^{30}$

Pada saat ini toko bahan bangunan milik Haji Abdul Karim berjumlah 13 (tiga belas), Setelah membuka toko bangunan sendiri Haji Abdul Karim juga melakukan hal yang sama dengan pendahulunya yaitu Haji Muntaham, Haji Abdul Karim mengajak beberapa ponakkannya baik ponakkan sendiri maupun dari pihak istri untuk bekerja pada toko bangunan milik. Tradisi melibatkan saudara dalam menjalankan usaha ini dilakukan hampir semua pelaku usaha Sari Bumi, sehingga bisnis ini menjadi berkembang dengan memiliki komunitas usaha, khususnya didaerah Sidoarjo.

5. Memberi bantuan modal.

Selain mengajak dan melatih untuk menjadi pengusaha pada jenis yang sama, para entrepreneur Sari Bumi juga saling memberi bantuan modal pada anggota yang membutuhkan. Hal ini diungkapkan oleh Haji Abdul Karim:

"Bahwa prinsip yang diterapkan oleh Haji Muntaham Allahu yarham itu ingin mengangkat kerabatnya agar memiliki usaha semua, misalnya dalam satu keluarga keponakkannya ada beberapa, beliau ambil satu dilatih sampai bisa usaha sendiri kemudian diberi pinjaman modal tanpa bunga, ketika ponakkannya tersebut masi ikut kerja sebagai karyawan pada toko Haji Muntaham, honornya tidak

30 Abdul Karim, "wawancara", Toko Sari Bumi Raya Kav DPR A II Sidoklumpuk, 24 April 2018. 
diberikan secara penuh, tetapi honornya hanya diberikan sebagian saja, lainnya di tabung, kemudian uang hasil tabungan inilah yang dijadikan modal awal untuk membuka usaha sendiri". ${ }^{31}$

Dalam hal bantuan modal ini selain dengan cara bantuan secara langsung, komunitas entrepreneur Sari Bumi juga memiliki kelompok arisan keluarga, arisan ini sangat membantu dalam hal permodalan, karena system arisan ini tidak diundi seperti arisan pada umumnya, tetapi arisan ini diberikan pada anggota berdasarkan tingkat tingginya kebutuhan. Jadi sebelum pertemuan arisan, pengurus arisan berembuk untuk memastikan siapa yang berhak memperoleh arisan pada bulan tersebut, jika ada beberapa anggota yang mengajukan maka akan dievaluasi siapa yang paling berhak mendapat arisan berdasarkan masalah permodalan yang mereka hadapi. Seperti yang telah diungkap pada hasil penelitian bahwa arisan sari bumi saat ini seharga satu unit mobil.

6. Menjadi teladan dalam kedisiplinan dan pelayanan terhadap pelanggan.

Dalam menjaga kedisiplinan hal ini diungkapkan oleh ibu Indah Kuzfaza, salah satu responden dalam penelitian ini:

"Yang selalu kami contoh dari para pemilik toko Sari Bumi adalah tentang kedisiplinannya, toko Sari Bumi selalu buka jam 6 (enam) pagi dan apabila jam istirahat siang toko Sari Bumi juga tidak tutup para karyawan bergantian makan siang dan solat duhur. Selain tentang waktu, toko Sari Bumi juga tidak menerapkan libur ditanggal merah atau hari hari besar karena ditanggal merah dan hari libur banyak pelanggan yang berkesempatan untuk memperbaiki rumah mereka. Walaupun tidak menerapkan hari libur toko Sari Bumi tetap memberikan kesempatan berlibur bagi

31 Abdul Karim, "wawancara", Toko Sari Bumi Raya Kav DPR A II Sidoklumpuk, 24 April 2018. 
karyawan mereka dengan cara bergantian atau system rowling. ${ }^{32}$

Selain ibu Indah Kuzfaza Haji Abdul Karim juga mengungkapkan hal yang sama tentang hal ini. Beliau mengungkapkan kedisiplinan ini sangat ditekankan oleh Haji Muntaham perintis awal toko Sari Bumi ini, zaman dahulu tidak ada toko bangunan yang buka paling pagi kecuali toko bangunan Sari Bumi, kami buka jam 6 (enam) pagi dan baru tutup jam 5 (lima) sore. ${ }^{33}$

7. Komitmen dalam menjaga nilai-nilai keIslaman

Sebagai pribadi muslim para entrepreneur Sari Bumi selalu menjaga nilai-nilai Islam dalam kehidupan mereka, baik dalam urusan ekonomi maupun urusan lainnya, hal ini seperti disampaikan oleh Haji Anas Asrofi tentang Haji Muntaham perintis usaha Sari Bumi, "Beliau Haji Muntaham orang yang rajin dalam beribadah, dimanapun beliau berada tempat pertama yang ditujuh adalah masjid, beliau sangat menjaga solat, baik solat sunnah maupun solat wajib, kecintaanya terhadap masjid dibuktikan dengan kepedulian beliau terhadap masjid, beliau aktif dibeberapa masjid baik sebagai pengurus maupun jamaah pengajian". ${ }^{34}$ Sedangkan dalam urusan ekonomi para entrepreneur Sari Bumi sangat menjaga nilai - nilai ke Islaman, salah satu hal yang sangat dijaga adalah mereka berupaya untuk tidak meminjam uang di Bank untuk memenuhi modal mereka, dalam transaksi biasa pun para entrepreneur Sari Bumi lebih memilih bank Syariah karena untuk menjaga diri dari bersentuhan dengan riba. ${ }^{35}$ Dalam urusan ibadah lain, ibadah haji misalnya para entrepreneur sangat menganjurkan para anggotanya untuk segera daftar haji, apabila kekurangan dana mereka saling membantu, seperti disampaikan oleh Hajjah Onik Faoeziyah

${ }^{32}$ Indah Kuzfaza, "wawancara”, Toko Bangunan Karya Gemini Tanggulangin, 26 April 2018.

${ }^{33}$ Abdul Karim, "wawancara", Toko Sari Bumi Raya Kav DPR A II Sidoklumpuk, 24 April 2018.

${ }^{34}$ Anas Asrofi, "wawancara", Kantor Sari Bumi Bangunan, 10 April 2018.

35 Ibid. 
responden dalam penelitian ini, ketika beliau dan suaminya akan berangkat Haji maka segala kebutuhan selama perjalanan haji dan segala macam oleh-oleh untuk menyambut kedatangan haji semua disediakan oleh keluarga besar Sari Bumi dengan cara saling membantu diantara mereka. ${ }^{36}$ Begitu juga dalam urusan aqiqah atas kelahiran putra atau putri anggota mereka, mereka saling membantu.

8. Membentuk wadah silaturahmi

Untuk menjalin komunikasi yang intens para entrepreneur Sari Bumi membentuk wadah silaturahmi berupa pertemuan dua kali dalam satu bulan, pertemuan ini dikemas dalam bentuk arisan dan pengajian dengan mendatangkan ustadz. Pertemuan ini selain sebagai wadah menambah ilmu pengetahuan juga saling evaluasi dalam urusan bisnis. Dengan adanya intensitas pertemuan ini banyak mewujudkan ide-ide bersama seperti terbentuknya yayasan sosial yang bergerak pada bidang pendidikan, sosial dan keagamaan. Selain hal tersebut dengan adanya wadah pertemuan rutin, mereka memiliki kesempatan untuk saling bertemu, berbagi informasi juga saling membantu diantara mereka.

9. Mendirikan yayasan yang berkipra pada bidang sosial, pendidikan dan keagamaan.

Untuk memperluas perannya di masyarakat komunitas pengusaha Sari Bumi mendirikan yayasan, salah satu kipra yang dapat dirasakan masyarakat sekitar adalah dengan adanya lembaga pendidikan Sari Bumi, yang terdiri dari Taman Pendidikan Al-Qur'an (TPQ), Pendidikan Anak Usia Dini (PAUD) dan Sekolah Dasar Islam Sari Bumi (SD Islam Sari Bumi). Lembaga pendidikan Sari Bumi merupakan lembaga pendidikan yang menjadi altefnatif masyarakat yang berkeinginan menguatkan karakter keagamaan pada putra - putri mereka. Karena selain mengikuti kurikulum

36 Onik Faoeziyah, "wawancara", Toko Sari Bumi Bangunan Urang Agung, 04 Februari 2018. 
pemerintah lembaga pendidikan Sari Bumi juga menerapkan kurikulum local berupa program - program unggulan, seperti market day, yaitu hari dimana siswa diwajibkan membawa dagangan kesekolah, hal ini untuk menumbuhkan jiwa entrepreneur pada peserta didik. Selain market day, sekolah Sari Bumi juga memiliki target hafalan Al-Qur'an tiga juz bagi siswa yang telah lulus dari SD Islam Sari Bumi. Karena beberapa keunggulan program pada sekolah Sari Bumi, sekolah ini sudah merupakan salah satu lembaga pendidikan favorit di kabupaten Sidoarjo, hal ini terbukti dengan banyaknya wali murid yang mendaftarkan putraputrinya pada lembaga pendidikan Sari Bumi. Walaupun banyak calon peserta didik yang tidak diterima pada lembaga pendidikan Sari Bumi karena lembaga ini menerapkan system seleksi yang sangat ketat, hal ini mereka lakukan untuk benar-benar menemukan peserta didik yang berkualitas yang siap menerima program-program unggulan yang mereka terapkan pada sekolah tersebut.

10. Mendirikan perusahaan distributor.

Untuk menjaga eksistensi bisnis toko bahan bangunan ditengah maraknya persaingan bisnis dimasyarakat, maka para entrepreneur Sari Bumi pada tahun 2012 dipelopori Haji Anas Asrofi mendirikan Holding Bumi, Holding Bumi adalah perusahaan distributor, yaitu perusahaan yang berfungsi sebagai penyedia bahan - bahan bangunan yang memasok barang kepada toko bahan bangunan yang dimiliki oleh komunitas pengusaha Sari Bumi. Perusahaan tersebut diberi nama Holding Bumi, Holding Bumi merupakan perusahaan distributor bahan - bahan bangunan yang dimiliki oleh komunitas pengusaha Sari Bumi.

\section{Strategi Entrepreneur Sari Bumi dalam membangun dan Menjaga Keberlangsungan Bisnis}

Strategi Bisnis, strategi dalam Kamus Bahasa Indonesia bermakna, ilmu dan seni menggunakan sumberdaya, untuk melaksanakan suatu kebijakkan tertentu dalam keadaan 
perang maupun damai. Strategi dapat juga dikatakan sebagai rencana yang cermat untuk mencapai sasaran yang khusus. ${ }^{37}$ Sedangkan strategi menurut David (2012) dalam Ammar, merupakan sarana bersama dalam tujuan jangka panjang yang hendak dicapai, strategi bisnis bisa merupakan perluasan giografis, diversifikasi, akuisisi, pengembangan produk, penetrasi pasar, rasionalisasi karyawan, divestasi, likuidasi dan usaha patungan atau join venture. ${ }^{38}$

Strategi memberi jawaban bagi pihak manajemen mengenai bagaimana cara mencapai tujuan perusahaan dan bagaimana caranya untuk mencapai misi organisasi dan visi strategis. Pembuatan strategi adalah tentang bagaimana mencari target-target, bagaimana bersaing dengan para kompetitor, bagaimana mencapai keunggulan bersaing yang berkepanjangan, bagaimana membuat visi strategis manajemen sebagai sebuah kenyataan bagi suatu perusahaan.

Dalam merumuskan suatu strategi operasi dan persoalan strategi bisnis, suatu analisis harus dibuat berdasarkan lingkungan eksternal dan internal. Lingkungan eksternal biasanya meliputi persaingan, pelanggan, ekonomi, teknologi dan kondisi sosial. Lingkungan eksternal selain dapat membentuk strategi bisnis dan strategi perusahaan juga dapat membentuk strategi operasi. Suatu analisis lingkungan internal bisanya mengarah pada pengidentifikasian kekuatan dan kelemahan operasi yang ada. Strategi operasi mencoba mengatasi kelemahan dan mengembangkan kekuatan yang ada.

Berdasarkan hasil penelitian ada beberapa strategi bisnis yang digunakan oleh para entrepreneur Sari Bumi untuk menjaga keberlanjutan usaha mereka, yaitu dengan:

1. Perluasan geografis.

\footnotetext{
37 Pusat Bahasa Departemen Pendidikan Nasional, Kamus Besar Bahasa Indonesia. 1092

38 Mochamad Ammar Faruq, "Penyusunan Strategi Bisnis Dan Strategi Operasional Usaha Kecil Dan Menengah Pada Perusahaan Konveksi Scissors Di Surabaya," Jurnal Managemen Teori dan Terapan No.3 (n.d.): 173.
} 
Perluasan giografis atau perluasan wilayah, dilakukan melalui pendekatan kekeluargaan. Berawal dari perintis usaha ini yaitu Haji Muntaham membuka satu toko bangunan didaerah Rungkut, kemudian Haji Muntaham melibatkan Haji Abdul Karim yang pada tahun 1982 masi kuliah, Haji Abdul Karim bekerja paruh waktu sambil kuliah. Kemudian Haji Muntaham membuka toko bangunan lagi di daerah Medokkan dan Haji Abdul Karim bersama istri sebagai operasionalnya. Kemudian pada toko pertama Haji Muntaham melibatkan saudaranya yang lain, yaitu Haji Ahmad Sya'i, Haji Ahmad Khoiri dan Ibu Siti Muthahara. Kemudian Haji Abdul Karim membuka toko sendiri di daerah Blurukidul Sidoarjo, Haji Ahmad Sya'i juga membuka sendiri di daerah Jambangan Surabaya, Haji Ahmad Khoiri membuka sendiri di daerah lingkar timur Sidoarjo, sedangkan ibu Siti Muthahara membuka sendiri di daerah Ngampelsari Sidoarjo. Dan masing-masing dari mereka juga melibatkan saudara-saudaranya dalam menjalankan operasional toko bangunan tersebut. Sehingga masing-masing dari mereka memiliki toko lebih dari satu, sesuai data penelitian Haji Abdul Karim memiliki 13 toko, ibu Siti Muthahara memiliki 6 toko, Ahmad Sya'i memiliki 6 toka sedangkan Ahmad Khoiri memiliki 2 toko. Selanjutnya masing-masing dari pemilik toko bangunan yang tergabung dalam komunitas Sari Bumi melibatkan saudara mereka, sehingga saat ini, berdasarkan data penelitian, ada 158 toko bahan bangunan Sari Bumi yang dimiliki oleh 80 orang.

2. Diversifikasi.

Diversifikasi merupakan usaha penganekaragaman produk, atau lokasi produksi yang dilakukan untuk memaksimalkan keuntungan agar arus kas perusahaan dapat stabil. Istilah diversifikasi di terjemahkan dalam bahasa Haji Anas Asrofi dengan berjualan "tulang dan daging". Berjualan tulang maksudnya berjualan bahanbahan bangunan yang pokok seperti macam-macam pasir, macam-macam batu, dan barang bangunan yang 
membutuhkan biaya operasional dan mengalami penyusutan, barang-barang tersebut hampir dijual disetiap toko bangunan. Sedangkan berjualan daging yang dimaksud Haji Anas Asrofi adalah berjualan macam-macam kelengkapan bangunan yang jarang disediakan di toko bangunan lainnya, barang-barang tersebut adalah, macammacam engsel pintu dan jendela, pipa dan bahan pelengkap bangunan lainnya. Bahan-bahan tersebut tidak membutuhkan operasioanal yang tinggi karena tidak mengalami penyusutan dan tidak membutuhkan biaya pengiriman. Tetapi barang-barang tersebut selalu dibutuhkan konsumen. Strategi inilah yang di sarankan Haji Anas Asrofi kepada seluruh anggota entrepreneur Sari Bumi, agar toko bangunan mereka bisa eksis ditengah persaingan usaha yang sangat ketat ini.

3. Penetrasi pasar.

Merupakan upaya meningkatkan penjualan produk dengan menguatkan aspek promosi. Berdasarkan pengamatan peneliti beberapa kali Sari Bumi dimuat dibeberapa media yang berupa surat kabar dan majalah bisnis. Selain hal tersebut, yang lazim dilakukan para pengusaha Sari Bumi adalah melakukan media promosi secara sederhana dengan mengaktifkan beberapa organisasi komunitas, seperti mengaktifkan pertemuan Ar-rihlah. Ar-rihlah merupakan pertemuan rutin antar sesama pengusaha bahan bangunan di kabupaten Sidoarjo. Salah satu fungsi pertemuan ini adalah diskusi tentang kerjasama bisnis diantara para pengusaha bahan bangunan. Selain pertemuan Ar-rihlah juga memperbanyak anggota pertemuan rutin pengusaha Sari Bumi.

4. Akuisisi.

Akuisisi adalah strategi pengambilalihan perusahaan oleh pemilik lain. Akuisisi juga beberapa kali dilakukan oleh pengusaha Sari Bumi hal ini disampaikan oleh Haji Anas Asrofi, bahwa H Muntaham membeli beberapa toko bangunan yang dijual pemiliknya untuk dikelolah dan dikembangkan. 
5. Rasionalisasi karyawan.

Rasionalisasi memiliki arti proses melakukan tindakan yang rasional untuk memperbaiki perusahaan. Rasionalisasi yang dilakukan oleh para entrepreneur Sari Bumi bukan pengurangan karyawan seperti kebanyakan perusahaan, tetapi berupa pembayaran $50 \%$ dari honor karyawan, dan yang 50 \% lainnya ditabung. Strategi ini dapat menguntungkan kedua bela pihak. Bagi pihak pemilik toko gaji karyawan yang belum dibayarkan dapat sebagai tambahan perputaran modal usaha, sedangkan bagi karyawan hal ini juga bermanfaat, karena dengan ditabung karyawan dapat memiliki dana yang berkembang dan lambat laun dana tersebut akan mereka ambil sebagai modal membuka toko bahan bangunan sendiri.

6. Pengembangan usaha

Pengembangan usaha dilakukan dengan cara mendirikan perusahaan distributor, yaitu Holding Bumi. Holding Bumi didirikan pada tahun 2012 setelah kurang lebih 30 tahun komunitas Sari Bumi berproses dalam usaha bahan bangunan. Untuk menjaga agar menjadi komunitas pengusaha yang mandiri dan tidak banyak tergantung pada pemasok lain mereka mendirikan perusahaan distributor.

7. Usaha patungan atau join venture.

Join venture atau usaha patungan dilakukan dengan membuka perusahaan distributor, yaitu Holding Bumi. Holding Bumi merupakan perusahaan distributor bahanbahan bangunan yang dimiliki oleh komunitas pengusaha Sari Bumi, saat ini perusahaan tersebut dimiliki 38 (tiga puluh delapan) orang sebagai pemegang sahamnya.

\section{Penutup}

Beberapa peran yang dilakukan oleh entrepreneur Sari Bumi dalam membangun koneksi dan komunitas bisnis adalah: 1). Selalu menjalin hubungan baik dan menghargai orang lain, 2). Menjaga reputasi, 3). Selalu berbagi dengan relasi bisnis, baik tentang informasi maupun hal lain yang dapat saling menguntungkan dalam hubungan bisnis. 4). Membangun 
hubungan baik melalui komunikasi yang effektif. 5). Selalu menjaga performa dan persepsi diri sebagai entrepreneur.

Sedangkan dalam melakukan peran tersebut ada beberapa strategi yang dilakukan entrepreneur Sari Bumi yaitu: 1). Perluasan geografis yang dilakukan melalui pendekatan kekeluargaan, 2). Melakukan diversifikasi atau penganekaragaman produk, dengan cara melengkapi toko bahan bangunan agar pelanggan dapat terlayani dengan baik, 3). Penetrasi pasar, merupakan upaya meningkatkan penjualan produk dengan menguatkan aspek promosi, 4). Akuisisi, dengan cara membeli toko bangunan yang dijual pemiliknya karena suatu hal, 5). Rasionalisasi karyawan, 6). Melakukan pengembangan usaha dengan cara mendirikan perusahaan distributor, yaitu Holding Bumi, 7). Usaha patungan atau join venture, Holding Bumi merupakan perusahaan bersama-sama yang sahamnya dimiliki oleh 38 (tiga puluh delapan) anggota pengusaha toko bahan bangunan Sari Bumi.

\section{Daftar Pustaka}

Al-Qardhawi, Yusuf. Fiqih Maqasid Syari'ah. Jakarta: Pustaka Kautsar, 2007.

Antonio. Ensiklopedi Bisnis \& Kewirausahaan, n.d.

Antonio, Muhamad Syafii. Ensiklopedi Leadership \& Manajemen The Super Leader Super Manager, Seri Business \& Entrepreneurship. Jakarta: Tazkia Publising, 2010.

Antonio, Syafi'i. Bisnis \& Kewirausahaan, n.d.

Darwanto. Peran Entrepreneurship Dalam Mendorong Pertumbuhan Ekonomi Dan Meningkatkan Kesejahteraan Masyarakat. Semarang: Diseminasi Riset Terapan Bidang Manajemen dan bisnis Tingkat Nasional Jurusan Politehnik Negeri Semarang, 2012.

Faruq, Mochamad Ammar. "Penyusunan Strategi Bisnis Dan Strategi Operasional Usaha Kecil Dan Menengah Pada Perusahaan Konveksi Scissors Di Surabaya." Jurnal Managemen Teori dan Terapan No.3 (n.d.): 173. 
Firdaus. "Konsep Ketuhanan Dalam Al-Qur'an." Jurnal Diskursus Islam Vol.3 No.1 (2015): 103.

Frinces, Z Heflin. "Pentingnya Profesi Wirausaha Di Indonesia." Jurnal Ekonomi \& Pendidikan Vol.7 No.0 (n.d.): 44.

Hosen, Nadratuzzaman. "Analisis Bentuk Gharar Dalam Transaksi Ekonomi." Jurnal Al-iqtishad Vol.1 No.1 (n.d.): 57.

Meshel, Jeffrey W. Secrets of Master Networker: 35 Strategi Membangun Relasi Bisnis Sehari-Hari. Jakarta: PT. Bhuana Ilmu Populer, 2005.

Mursal. "Implementasi Prinsip-Prinsip Ekonomi Syariah, Alternative Mewujudkan Kesejahteraan Berkeadilan." Jurnal Prespektif Ekonomi Darussalam Vol. 1, No (2015): 75.

Pusat Bahasa Departemen Pendidikan Nasional. Kamus Besar Bahasa Indonesia, n.d.

-_- Kamus Besar Bahasa Indonesia. Ke-3. Jakarta: Balai Pustaka, 2003.

Shihab, Quraish. Membumikan Al-Qur'an. Bandung: Mizan, 1994.

Syayuti. "Pemerintah Pasar Dan Komunitas Faktor Utama Dalam Pengembangan Agribisnis Di Pedesaan." Forum Penelitian Agro Ekonomi Vol. 22 No (n.d.): 58.

Abdul Karim, "wawancara”, Toko Sari Bumi Raya Kav DPR A II Sidoklumpuk, 24 April 2018.

Amsikul Ma'arif, "wawancara", Toko Sari Bumi Bangunan Urang Agung, 04 Februari 2018

Anas Asrofi, "wawancara", Kantor Sari Bumi Bangunan, 10 April 2018.

Ida Mufida, "wawancara", Toko Sari Bumi Raya Kav DPR A II Sidoklumpuk, 24 April 2018 
Fenomenologi Pelaku Usaha Sari Bumi Sebagai Entrepreneur Muslim Dalam ...

Indah Kuzfaza, "wawancara", Toko Bangunan Karya Gemini Tanggulangin, 26 April 2018.

Onik Faoeziyah, "wawancara", Toko Sari Bumi Bangunan Urang Agung, 04 Februari 2018.

Siti Muthaharah, "wawancara", Sari Bumi Ngampelsari, 19 April 2018.

Syamil, "wawancara", Toko Bangunan Karya Gemini Tanggulangin, 26 April 2018. 